Review

\title{
Mycotoxicoses in children
}

\author{
Maja Peraica ${ }^{1}$, Darko Richter ${ }^{2}$, and Dubravka Rašić ${ }^{1}$ \\ Unit of Toxicology, Institute for Medical Research and Occupational Health ${ }^{1}$, Department of Paediatrics, \\ University Hospital Centre Zagreb², Zagreb, Croatia
}

Received in July 2014

CrossChecked in July 2014

Accepted in November 2014

\begin{abstract}
Mycotoxicoses are acute and chronic poisonings caused by mould toxins called mycotoxins. Although acute mycotoxicoses, caused by high mycotoxin levels in food are rare nowadays, they need to be described in order to inform physicians and other health care workers about their symptoms. Children are more sensitive to mycotoxins because of their lower body mass, higher metabolic rate, and underdeveloped organ functions and detoxication mechanisms. Some mycotoxicoses appear only in children, and some are more pronounced in children than in adults. Acute mycotoxicoses in children are reported poorly, mostly because they occur in the tropical regions with poor healthcare coverage. In developed countries healthcare authorities are more concerned about child exposure to low levels of mycotoxins with immunotoxic, genotoxic or carcinogenic properties.
\end{abstract}

KEY WORDS: 3-NPA; aflatoxins; ergot; fumonisins; ochratoxins; trichothecenes; Ustilago maydis toxins; zearalenone

Mycotoxins are the metabolites of moulds (fungi imperfecti) that contaminate food and feed around the world. Humans are continuously exposed to mycotoxins, as not even good agricultural and production practices can entirely prevent their production. Mould growth and the production of mycotoxins depend on the genetic properties of individual mould species and on environmental conditions such as temperature, humidity, and insect infestation. Grains are usually contaminated with several mycotoxins, which may either be the consequence of contamination with several strains of moulds, each producing its own mycotoxin, or of the production of several mycotoxins by one mould species. Out of about 400 known mycotoxins, only a few have been investigated in detail in laboratory animals and even fewer have known toxic and other health-threatening effects in humans.

The main route of exposure in humans is ingestion of contaminated food, but for some mycotoxins inhalation or dermal exposure are also possible. It is very difficult to assess the health risks associated with mycotoxins in children, as reliable exposure data are seldom available, mycotoxins often occur with other mycotoxins or other toxins, other dietary elements and contaminants affect their toxicity, and many diseases induced by mycotoxins have long latency (1).

For most mycotoxins there are no epidemiological data on their carcinogenicity in humans, but for some (such as aflatoxin B1) there is convincing evidence of an association with human hepatocellular carcinoma. Other mycotoxins (such as ochratoxin A, patulin, and fumonisin B1) are suspected to be human carcinogens due to positive results in experimental animals (2). Young animals and children are more sensitive to the adverse effects of mycotoxins than adults because of lower body mass, higher metabolic rate, and underdeveloped organ functions and detoxication mechanisms.

Most mycotoxins may cause acute and chronic mycotoxicoses. Acute mycotoxicoses are serious diseases caused by exposure to very high mycotoxin 
levels. They are most common in tropical regions where exposure of children to certain mycotoxins, particularly aflatoxins, is continuously high. Conversely, chronic mycotoxicoses are associated with low-level exposure. Mycotoxicoses are important differential diagnoses and should be taken into consideration when a clinical disorder affects a group of persons in whom it cannot be related to an infectious agent.

Even though clinical symptoms and the outcome are more severe in children than adults, mycotoxicosis reports seldom distinguish the two groups.

This article is an attempt to review what little is known about mycotoxicosis in children and the available data on mycotoxins and biomarkers of exposure to mycotoxins in various biological materials (blood of pregnant women, umbilical cord blood, blood and urine of children).

\section{Aflatoxins}

Aflatoxins B1 (AFB1), B2 (AFB2), G1 (AFG1), and $\mathrm{G} 2$ (AFG2) are mycotoxins produced by Aspergillus spp. Their names come from the colour of their fluorescence (B - blue, $\mathrm{G}$ - green). The most common and also the most toxic is AFB1. In the organism, $\mathrm{AFB} 1$ and $\mathrm{AFG1}$ are metabolised to various compounds, including aflatoxin M1 (AFM1) and M2 (AFM2), which appear in human and cow milk, urine, and faeces.

Aflatoxins contaminate nuts, maize, sorghum, millet, beans, cassava, and rice, whereas their metabolites AFM1 and AFM2 contaminate milk and dairy products.

Animal studies show that, apart from being acutely toxic, aflatoxins are immunosuppressive, mutagenic, teratogenic, and carcinogenic (2). The target organ of their toxicity and carcinogenicity is the liver. The International Agency for Research on Cancer (IARC) has classified natural mixtures of AFs as carcinogenic in humans (Group 1) and AFM1 as potentially carcinogenic in humans (Group 2) (2).

Aflatoxins are well absorbed by the gastrointestinal (GI) tract and transported to the liver, where they are metabolised by a number of competitive pathways. They are bioactivated mainly by cytochrome P450 (CYP) 3A enzymes (CYP3A4, CYP3A5, and CYP3A7) in the first oxidative phase. AF activation is also possible in the small intestine due to the presence of CYP3A4 and CYP3A5. About 1-3\% of the absorbed AFs is activated to highly mutagenic exo-epoxide (AFB1-8,9-epoxide), whose half-life $\left(t_{1 / 2}\right)$ is only one second in aqueous buffer but long enough to react with DNA to yield $98 \%$ of the $\mathrm{N}^{7}$-guanyl adduct. Wojnowski et al. (4) have associated high levels of the mutagenic AFB1 exo-8,9-epoxide in humans exposed to dietary $\mathrm{AFB}_{1}$ with the CYP3A5 polymorphism, particularly in individuals with low CYP3A4. AFB 8,9-epoxides hydrolyse to nongenotoxic dihydrodiol, which is further metabolised to its dialdehyde (5). The amount of $\mathrm{AFB}_{1}$-DNA adducts is greater in the liver than in other organs and generally correlates with $\mathrm{AFB}_{1}$ levels and species susceptibility to hepatocarcinogenesis (6). DNA- and albumin-AFB1 adducts (AFB1-DNA, AFB1-alb) are reliable biomarkers of long-term exposure to AFB1. The major detoxication route for $\mathrm{AFB}_{1}$ metabolites is via conjugation with glutathione (GSH) to form the $\mathrm{AFB}_{1}$-GSH conjugate excreted in urine and bile, and this reaction determines species resistance to aflatoxin toxicity (7).

In some regions of Africa and Asia the risk of hepatocellular carcinoma (HCC) is very high, particularly in hepatitis B surface antigen-positive $\left(\mathrm{HBsAg}^{+}\right)$persons. Without $\mathrm{AF}$ exposure, the relative risk of $\mathrm{HCC}$ development in $\mathrm{HBs} \mathrm{Ag}^{+}$persons is 7.3, but with AFs exposure it soars to about 60 (8). In adults, AFs cause deletional mutations in the P53 tumour-suppressing gene and therefore activate oncogenes. However, in two to five-year-old children in Guinea with high AF-albumin adduct levels Turner et al. (9) found no mutations in P53 tumoursuppressing gene, which suggests that children could be protected from high AF carcinogenicity if vaccinated against $\mathrm{HBV}$ infection, as it significantly increases the risk of HCC. In order to decrease the risk of HCC, South Africa has recently introduced vaccination against $\mathrm{HBV}$ infection in infants (receiving three shots by their $14^{\text {th }}$ week). In a five-year follow up Tsebe et al. (10) reported that this vaccination decreased significantly the $\mathrm{HBsAg}^{+}$carrier rate in children younger than five years.

Exposure to AFs may be assessed by measuring parent compound or metabolites in blood and urine, or AFB1-alb and AFB1-DNA adducts in blood. The first method is only reliable for recent exposure to AFs because of their fast metabolism and therefore a tendency to underestimate longer exposure. This is probably why there were no AFB1-positive urine findings in children from Cameroon, even though $11 \%$ of the samples showed the presence of its metabolite AFM1 (11). The second method that measures AF-alb 
and AF-DNA adducts is therefore more reliable for longer exposures (2-3 months).

Aflatoxicosis is a clinical condition following exposure to aflatoxins. Acute aflatoxicosis is a severe poisoning that results in serious liver damage, often with fatal outcome. Chronic aflatoxicosis is the consequence of exposure to lower levels of AFs over a longer period and may have chronic nutritional and immunological consequences. In terms of cancer risk, the effects are cumulative.

The first report of acute AF hepatotoxicity in children dates back to 1971 (12), when 20 malnourished children from 1.5 to 5 years of age were hospitalised for symptoms of acute liver damage, 13 of whom were subicteric. They had been eating a peanut protein meal contaminated with aflatoxin $\left(30 \mu \mathrm{g} \mathrm{kg}^{-1}\right)$ from five days to one month. At the end of the one-year follow up, 12 had gross hepatomegaly and three had palpable liver with sharp edges. Three children died from hepatic coma after 1.5 years.

Another outbreak of acute aflatoxicosis in India in 1974 practically spared the children under the age of five years, who made about $8 \%$ of the affected patients $(13,14)$. In the most severe aflatoxicosis outbreak in Kenya in 1981, the number of affected children was never established (15), but in the outbreak of 2004, it was half of those whose age data was known (308 of 317 people). Sixty eight children were under the age of five and 90 from five to fifteen (16).

Exposure to AFs in utero in Africa is alarming (Table 1). The findings of AFs in umbilical cord blood from 1988 were the first to evidence transplacental transport of AFs in humans (17). Egyptian researchers established a significant negative correlation between birth weight and AF levels in umbilical cord blood $(18,20)$. In Gambia, a negative correlation was also found between AF-albumin adduct levels in mother's blood and weight and height gain in the first year of child's life (19).

It is estimated that up to $0.43 \%$ of AFs from consumed food is excreted as AFM1 in breast milk (21) and that mothers' exposure to AFs depends on their socioeconomic status $(22,23)$. In African countries, Turkey, Iran, and United Arab Emirates the frequency of AF-positive breast milk samples is rather high (Table 2). In Egypt and Gambia the concentrations of AFM1 in breast milk showed great seasonal variations $(16-96 \%)$, peaking in the dry season (summer) $(26,41)$. Breastfed children in Africa are exposed to lower AF concentrations than weaning children because the staple food in the weaning period is maize and cassava, which are often contaminated with AFs $(21,42,43)$. In Europe the frequency of AFM1-positive breast milk samples does not exceed $5 \%$, and the AFM1 levels are much lower than in Africa, but they still exceed the maximum tolerance limit for infant formula, follow-up formula, infant milk, and follow-up milk of $0.025 \mu \mathrm{g} \mathrm{kg}^{-1}$ in some European countries $(44,45)$.

Similar to breast milk, the frequency of AFpositive blood and urine samples of African children is high, and AF concentrations peak in the summer (Tables 3 and 4). In children from Gambia AF-albumin adduct levels in the summer are twice as high as in

Table 1 Reported aflatoxin and AF-alb adduct findings in umbilical cord blood in Africa

\begin{tabular}{|c|c|c|c|c|c|c|c|}
\hline \multirow[t]{2}{*}{ Country } & \multirow{2}{*}{$\begin{array}{c}\text { Positive } \\
\text { samples/ } \\
\text { analysed (N) }\end{array}$} & \multicolumn{5}{|c|}{$\begin{array}{l}\text { Positive by toxin } \\
\text { (N, positive samples/analysed, mean and range in } n g L^{-1} \text {, where available) }\end{array}$} & \multirow[t]{2}{*}{ Ref. } \\
\hline & & B1 & B2 & M1 & M2 & Method & \\
\hline Ghana* & $63 / 188(34 \%)$ & $\begin{array}{l}17 / 188(9 \%) \\
(185-43,822)\end{array}$ & $\begin{array}{c}17 / 188(9 \%) \\
(11-925)\end{array}$ & $\begin{array}{c}21 / 188(11 \%) \\
(34-7,320)\end{array}$ & $\begin{array}{c}21 / 188(11 \%) \\
(30-572)\end{array}$ & HPLC-FD & 17 \\
\hline Nigeria & $9 / 78(11 \%)$ & ND & $\begin{array}{c}1 / 78(1 \%) \\
10\end{array}$ & $\begin{array}{l}3 / 78(4 \%) \\
(25-8,942) \\
\end{array}$ & $\begin{array}{l}5 / 78(6 \%) \\
(155-378) \\
\end{array}$ & HPLC-FD & 17 \\
\hline $\begin{array}{l}\text { United } \\
\text { Arab } \\
\text { Emirates }\end{array}$ & $110 / 201(57 \%)$ & $\begin{array}{c}27 / 201(13 \%) \\
X=2,040 \\
(228-15,225)\end{array}$ & ND & $\begin{array}{c}107 / 201(53 \%) \\
X=1,108 \\
(110-4,060)\end{array}$ & $\begin{array}{c}31 / 201(15 \%) \\
X=854 \\
(210-3,700)\end{array}$ & HPLC-FD & 18 \\
\hline Gambia** & 49/99 (48 \%) & $\begin{array}{c}49 / 99(48 \%) \\
X=10.1 \\
(5.0-89.6) \\
\text { Median=2.5 }\end{array}$ & & & & ELISA & 19 \\
\hline
\end{tabular}


Table 2 Frequency of AFM1- and AFM2-positive breast milk samples and their concentrations across the continents

\begin{tabular}{|c|c|c|c|c|c|c|}
\hline \multirow[t]{2}{*}{ Country } & & \multirow{2}{*}{$\begin{array}{l}\text { No. positive/ } \\
\text { analysed }\end{array}$} & \multicolumn{2}{|c|}{$\begin{array}{l}\text { No. positive/analysed } \\
\text { (range } \text { n L L }^{-1} \text { ) }\end{array}$} & \multirow[t]{2}{*}{ Method } & \multirow[t]{2}{*}{ Ref. } \\
\hline & & & AFM1 & AFM2 & & \\
\hline & & & Africa & & & \\
\hline Cameroon & & $3 / 62(4.8 \%)$ & $\begin{array}{c}3 / 62(4.8 \%) \\
(5.0-62.5)\end{array}$ & & HPLC-FD & 24 \\
\hline \multirow{6}{*}{ Egypt } & Apr-Jun & $23 / 37(62 \%)$ & $\begin{array}{c}23 / 37(62 \%) \\
X=0.35(0.3-2.1)\end{array}$ & & \multirow{4}{*}{ HPLC-FD } & \multirow{4}{*}{25} \\
\hline & Sep-Dec & $16 / 45(35 \%)$ & $\begin{array}{c}16 / 45(35 \%) \\
X=0.34(0.3-1.9)\end{array}$ & & & \\
\hline & Jan-May & 27/38 (71\%) & $\begin{array}{c}27 / 38(71 \%) \\
X=0.3(0.2-1.6)\end{array}$ & & & \\
\hline & Total & $66 / 120(55 \%)$ & & & & \\
\hline & & $248 / 443(56 \%)$ & $\begin{array}{c}248 / 443(56 \%) \\
(4.2-889)\end{array}$ & & HPLC-FD & 26 \\
\hline & & $87 / 125(70 \%)$ & $\begin{array}{c}87 / 125(70 \%) \\
X=74.4(73-328)\end{array}$ & & ELISA & 27 \\
\hline Ghana & & $90 / 264(34 \%)$ & $\begin{array}{c}59 / 264(22 \%) \\
(20-1,816)\end{array}$ & $\begin{array}{c}18 / 264(7 \%) \\
(16-2,075)\end{array}$ & HPLC-FD & 17 \\
\hline Nigeria & & $41 / 50(82 \%)$ & $\begin{array}{l}41 / 50(82 \%) \\
(4.62-92.14)\end{array}$ & & HPLC-FD & 22 \\
\hline \multirow{2}{*}{ Sudan* } & & $37 / 99(37 \%)$ & $\begin{array}{c}26 / 99(26 \%) \\
X=19.0\end{array}$ & $\begin{array}{c}24 / 99(24 \%) \\
X=12.2\end{array}$ & HPLC-FD & 28 \\
\hline & & $51 / 94(54 \%)$ & $\begin{array}{c}51 / 94(54 \%) \\
X=0.41\end{array}$ & & HPLC-FD & 29 \\
\hline Zimbabwe & & $6 / 54(11 \%)$ & $\begin{array}{c}6 / 54(11 \%) \\
(0.2-50)\end{array}$ & & ELISA & 30 \\
\hline \multicolumn{7}{|c|}{ Middle East } \\
\hline Jordan & & $100 / 100(100 \%)$ & $\begin{array}{c}100 / 100 * *(100 \%) \\
X=68\end{array}$ & & ELISA & 31 \\
\hline $\begin{array}{l}\text { United Arab } \\
\text { Emirates }\end{array}$ & & $144 / 201(71 \%)$ & $\begin{array}{c}107 / 201(53 \%) \\
X=1,108 \\
(210-4,060)\end{array}$ & $\begin{array}{c}31 / 201(13 \%) \\
X=854 \\
(210-3,700)\end{array}$ & HPLC-FD & 18 \\
\hline \multicolumn{7}{|c|}{ Asia } \\
\hline \multirow[t]{5}{*}{ Iran } & Hamadan & $8 / 132(6 \%)$ & $\begin{array}{c}8 / 132(6 \%) \\
X=9.45 \\
(7.1-10.8)\end{array}$ & & ELISA & 32 \\
\hline & Sari & $1 / 136(0.7 \%)$ & $\begin{array}{c}1 / 136(0.7 \%) \\
20 * * *\end{array}$ & & ELISA & 33 \\
\hline & $\begin{array}{l}\text { Tabriz } \\
\text { (rural) }\end{array}$ & 20/91 (22 \%) & $\begin{array}{c}20 / 91(22 \%) \\
X=6.96\end{array}$ & & \multirow{2}{*}{ ELISA } & \multirow{2}{*}{20} \\
\hline & $\begin{array}{c}\text { Tabriz } \\
\text { (urban) }\end{array}$ & $0 / 91$ & & & & \\
\hline & Teheran & $157 / 160(98 \%)$ & $\begin{array}{c}157 / 160(98 \%) \\
X=8.2(0.3-26.7)\end{array}$ & & ELISA & 34 \\
\hline
\end{tabular}




\begin{tabular}{|c|c|c|c|c|c|}
\hline \multicolumn{6}{|c|}{ Europe } \\
\hline France & & $0 / 42$ & & ELISA & 30 \\
\hline \multirow[b]{2}{*}{ Italy } & Lombardi & $1 / 231(0.004 \%)$ & $\begin{array}{c}1 / 231(0.004 \%) \\
194 * * *\end{array}$ & HPLC-FD & 35 \\
\hline & & $4 / 82(5 \%)$ & $\begin{array}{c}4 / 82(5 \%) \\
X=55.3 \\
(7-140)\end{array}$ & HPLC-FD & 36 \\
\hline Turkey & & $75 / 75(100 \%)$ & $\begin{array}{c}75 / 75(100 \%) \\
(60.9-300.0)\end{array}$ & HPLC-FD & 37 \\
\hline \multicolumn{6}{|c|}{ South America } \\
\hline \multirow{3}{*}{ Brazil } & & $1 / 50(2 \%)$ & $\begin{array}{c}1 / 50(2 \%) \\
24 * * *\end{array}$ & HPLC-FD & 38 \\
\hline & & $2 / 224(0.01 \%)$ & $\begin{array}{c}2 / 224(0.01 \%) \\
5 * * *\end{array}$ & HPLC-FD & 39 \\
\hline & & $2 / 100(2 \%)$ & $\begin{array}{l}2 / 100(2 \%) \\
\quad>0.3 * * *\end{array}$ & HPLC-FD & 40 \\
\hline
\end{tabular}

$\overline{N D-\text { not detected; HPLC-FD-high pressure liquid chromatography with fluorescent detection; ELISA-enzyme-linked immunosorbent }}$ assay

*In 13 samples both AFM1 and AFM2 were found

**In $95 \%$ of samples the concentration of AFM1 was higher than $25 \mathrm{ng} \mathrm{L^{-1 }}$

***Concentration in a single or both samples

the winter (41). The highest AF-albumin adduct levels were found in children with acute hepatitis $B$, followed by children with chronic hepatitis, while healthy children had the lowest levels.

Although the immunotoxic effects of AFs in experimental animals are well known, there are no data on their immunotoxicity in children. In adults Jiang et al. (50) found a significant negative correlation between high AFB1-albumin adduct levels and the percentage of activated T and B cells. Denning et al. (51) believe that the immunotoxicity of AFs greatly contributed to acute lower respiratory tract infections in Filipino children, eleven of whom died, whereas Oyelami et al. (52.) found significant concentrations of AFs in the lung tissues of Nigerian children post mortem.

In a study of 479 blood samples taken from children from 9 months to five years in Benin and Togo, $99 \%$ were positive for AF-alb adducts (42). In this and another longitudinal study of 400 children from Benin peak serum AF-alb adducts in fully weaned children was 2.5 times higher than in partially breast-fed children $(23,46)$. These authors also found negative correlation between AF-alb adducts and children weight and height (46). In another study of children from Sierra Leone, the authors suggested that the failure to thrive may have been caused by exposure to AFs and another mycotoxin - ochratoxin A (OTA) (53).

In tropical countries neonatal jaundice is very frequent. A Nigerian study of 327 neonates with jaundice and 60 controls has demonstrated that glucose-6-phosphate dehydrogenase deficiency and/ or the presence of aflatoxins in serum are the risk factors for neonatal jaundice (54). A study performed in Kenya showed that school children with hepatomegaly, which is very frequent in this country, had significantly higher levels of AF-alb adducts than children without hepatomegaly (55).

Some diseases that affect children in tropical regions, such as Rey's syndrome and kwashiorkor were erroneously attributed to $\mathrm{AF}$ exposure $(56,57)$. Frequent post-mortem findings of AFs in various tissues of children with these diseases were probably the consequence and not the cause of liver injury. It is likely that their damaged liver could not metabolise the AFs.

\section{Ochratoxin A}

Ochratoxin A (OTA) is the most toxic and most common ochratoxin. Ochratoxins are produced by Penicillium verrucosum and several species of Aspergillus moulds from all over the world. They contaminate foodstuffs of plant origin (cereals, coffee 
beans, raisins, wine, beer, and grape juice) and commodities of animal origin such as pork and poultry meat, eggs, milk, and dairy products due to the carryover effect. Most data on food contamination with this heat-stable mycotoxin are from Europe (58).

In experimental and domestic animals the main target organs of OTA toxicity are the kidney and liver, but it also affects the heart, blood (causing aberrations in coagulation factors), GI tract, lymphoid tissue, and bone marrow. OTA is readily absorbed by the upper GI tract and persists in the circulation for a long time due to binding to plasma proteins, enterohepatic circulation, and kidney resorption, enhanced by organic anion transporters (59). Its plasma half-life in humans is 35.55 days (60), which is extremely long and makes plasma OTA a good biomarker of exposure. There are several mechanisms involved in OTA toxicity: production of reactive oxygen species, inhibition of mitochondrial respiration, disruption of calcium homeostasis, inhibition of protein synthesis, and DNA damage (61-65). IARC has classified OTA as carcinogenic in experimental animals with limited evidence for its carcinogenicity in humans (Group 2B) (66).

Despite severe acute toxicity in laboratory animals, ochratoxicosis is quite rare in humans (67). So far, no ochratoxicosis has been reported in children. Some researchers believe that OTA is involved in the development of Balkan endemic nephropathy (BEN) and otherwise rare urothelial tumours, whose incidence is high in the endemic regions of the Balkans $(68,69)$. In several studies performed in the endemic regions of Bulgaria and Croatia the level of OTA or the frequency of OTA-positive food and human blood samples were higher than in control regions (for a more comprehensive review see 70). Low OTA concentrations are frequently found in blood and urine of apparently healthy persons in all countries where it was looked for, with significant geographical and seasonal variations (70-72). Various studies have demonstrated that the blood levels of OTA are higher in patients with chronic renal insufficiency treated with dialysis (for a review see 73).

In Europe the calculated daily human exposure to OTA ranges from 0.7 to $4.7 \mathrm{ng} \mathrm{kg}^{-1}$ body weight (b.w.), which is below the tolerable daily intake of $14 \mathrm{ng} \mathrm{kg}^{-1}$ b.w. proposed by the Joint FAO/WHO Experts Committee on Food Additives and accepted by the European Scientific Committee (ESF) (57, 74). EFSA established the tolerable daily intake of $18 \mathrm{ng} \mathrm{kg}^{-1}$ b.w. (75).

Most data on child exposure to OTA are also from Europe. In Switzerland Zimmerli and Dick (76) reported twice as high OTA concentrations in the umbilical cord as that in maternal blood, indicating active transplacental transport of OTA.

Table 3 Aflatoxin B1-albumin adducts in blood of children

\begin{tabular}{|c|c|c|c|c|c|}
\hline Country & & Age (years) & $\begin{array}{c}\text { No. of positive/ } \\
\text { analysed }\end{array}$ & $\begin{array}{c}\text { AFB1-alb adducts pg } \mathrm{mg}^{-1} \\
\text { albumin } \\
\text { Mean (95\% CI) }\end{array}$ & Ref. \\
\hline \multirow{3}{*}{ Benin/Togo } & Fully weaned & $>3$ & & $45.6(38.8-53.7)$ & \multirow{3}{*}{42} \\
\hline & $\begin{array}{c}\text { Partially breast } \\
\text { fed }\end{array}$ & $<3$ & & $18.0(15.2-21.3)$ & \\
\hline & Total & $0.9-5$ & $475 / 479(99 \%)$ & $32.8(5-1064)$ & \\
\hline \multirow{4}{*}{ Gambia } & & 0.4 & $13 / 118(11 \%)$ & $8.7(5.0-30.3)^{*}$ & 19 \\
\hline & Healthy & \multirow{3}{*}{$3-4$} & $444 / 444(100 \%)$ & $31.6(2.2-495)$ & \multirow{3}{*}{41} \\
\hline & $\begin{array}{c}\text { Acute HBV } \\
\text { infection }\end{array}$ & & $\begin{array}{c}404 / 404(100 \%) \\
6 / 6\end{array}$ & $96.9(45.2-207.7)$ & \\
\hline & $\begin{array}{c}\text { Chronic HBV } \\
\text { infection }\end{array}$ & & $34 / 34(100 \%)$ & $44.9(32.3-62.5)$ & \\
\hline Guinea & & $2-5$ & 119/124 (96 \%) & $9.9(8-8-11.0)$ & 41 \\
\hline \multirow{2}{*}{ Taiwan } & $\begin{array}{c}\mathrm{HBsAg}^{-} \\
\text {(fmol mg-1 prot.) }\end{array}$ & \multirow{2}{*}{$13-15$} & 94 & $3.14 \pm 1.05^{* *}$ & \multirow{2}{*}{47} \\
\hline & $\begin{array}{c}\mathrm{HBsAg}^{+} \\
\text {(fmol mg-1 prot.) }\end{array}$ & & 105 & $3.47 \pm 0.85^{* *}$ & \\
\hline
\end{tabular}


OTA is also a frequent contaminant of breast milk. Its concentrations are about one quarter of those in maternal plasma (77) and the exposure of breast-fed children often exceeds the daily limit of $14 \mathrm{ng} \mathrm{kg}^{-1}$ b.w. (Table 5). In colostrum OTA concentrations are much higher than in mature breast milk. Obviously, breast milk OTA contamination is related to maternal dietary habits, which may vary from country to country. In Italy, significantly higher OTA concentrations in breast milk correlate with the consumption of bread, bakery products, and pork meat (36), while in Norway they correlate with the consumption of liver paste (liverwurst, liver paté) and cakes (cookies, fruitcakes, chocolate cakes) (86). An Egyptian study (78) looked at a number of biochemical parameters in blood and urine of breast-fed children with high and low levels of OTA in maternal milk and children's blood. Elevated OTA levels (in either milk or blood) correlated with a microglobulinuria, which was significantly greater in children with high than with low OTA concentrations and indicated initial kidney lesion. EFSA suggested that infants and children may experience higher rate of exposure than adults (75). It is not possible to link exposure to OTA during early childhood with any known human disease, although Schwartz (89) has put forward the hypothesis that mothers' consumption of OTAcontaminated food and OTA exposure in early childhood may be the cause of testicular cancer in adulthood. This theory is based on the correlation between the incidence of testicular cancer and percapita consumption of food items contaminated with OTA (coffee and pig meat) in 19 countries.

In tropical countries children are frequently exposed to OTA and AFs at the same time (44). Any health effect of this combination of mycotoxins, such as growth failure, could only be hypothesised (53). In a recent study in children in Cameroon under five years of age combined exposure to OTA and several other mycotoxins (AFs, fumonisin B1-FB1, deoxynivalenol - DON, zearalenone - ZEA, $\alpha$-zearalenol - $\alpha$-ZEA and $\beta$-zearalenol $\beta$-ZEA) did not correlate with the degree of malnutrition (11).

\section{Trichothecenes}

Trichothecenes are a group of about 170 mycotoxins produced mostly by the moulds of the Fusarium strains that are common in mild climates. Other strains that produce them include Trichoderma, Trichothecium, Myrothecium, and Stachybotrys. Only a few types of trichothecenes are found in grains (wheat, oats, maize, barley) for human and animal consumption. The most common are deoxynivalenol (DON previously called vomitoxin), nivalenol (NIV), and diacetoxyscirpenol (DAS), while T-2 toxin is rare. IARC has designated DON, NIV, and T-2 toxin not classifiable as to carcinogenicity to humans (Group 3) (66). Trichothecenes inhibit protein synthesis and activate mitogen-activated protein kinases (MAPKs) that are involved in immune response and apoptosis signalling (90). The main characteristic of trichothecenes toxicity is immunomodulation. Lower doses increase resistance to pathogens, up-regulate many immunerelated genes, and elevate serum IgA levels. Higher doses injure tissues with high cellular turnover such as bone marrow, lymph nodes, thymus, spleen, and intestinal mucosa. The consequence is a weaker immune response. In general, trichothecenes are haematotoxic and immunotoxic without genotoxic and carcinogenic properties (91-94).

Large outbreaks of acute mycotoxicosis caused by T-2 toxin, called alimentary toxic aleukia (ATA), were seen in the USSR in the 1930s and 40s. This disease mostly affected people from 10 to 40 years of age from rural areas because of the ingestion of grains that remained beneath the snow in the fields over the winter (95). Breast-fed infants of mothers affected by ATA were not ill. The first symptoms were local irritation of oral mucosa and painful swallowing. They developed after a few hours of ingestion of contaminated grains and subsided after two to three days if the exposure ceased. If it continued, the disease progressed to the second, leukopoenic stage with minimal symptoms, and then to progressive leucopoenia, granulocytopoenia, relative lymphocytosis, anaemia (low RBC or haemoglobin count), and thrombocytopoenia. In case of mild or discontinued exposure, patients would recover completely. The third stage was characterised by pharyngo-haemorrhagic symptoms with severe necrotic pharyngitis and petechial rush, characteristically involving the trunk, inner sides of the arms and hips, and the inguinal fossae. These symptoms were accompanied by nose and mouth bleeds and bleeding in the stomach and intestines. This stage of ATA had a mortality rate of $50 \%$. The fourth stage was the recovery stage when leukocytes counts started to increase, but it was also the stage when bacterial infections such as pneumonia and purulent tonsillitis appeared. Several later outbreaks of trichothecene toxicosis were not so severe. A large outbreak in the Kashmir Valley (India) also affected 


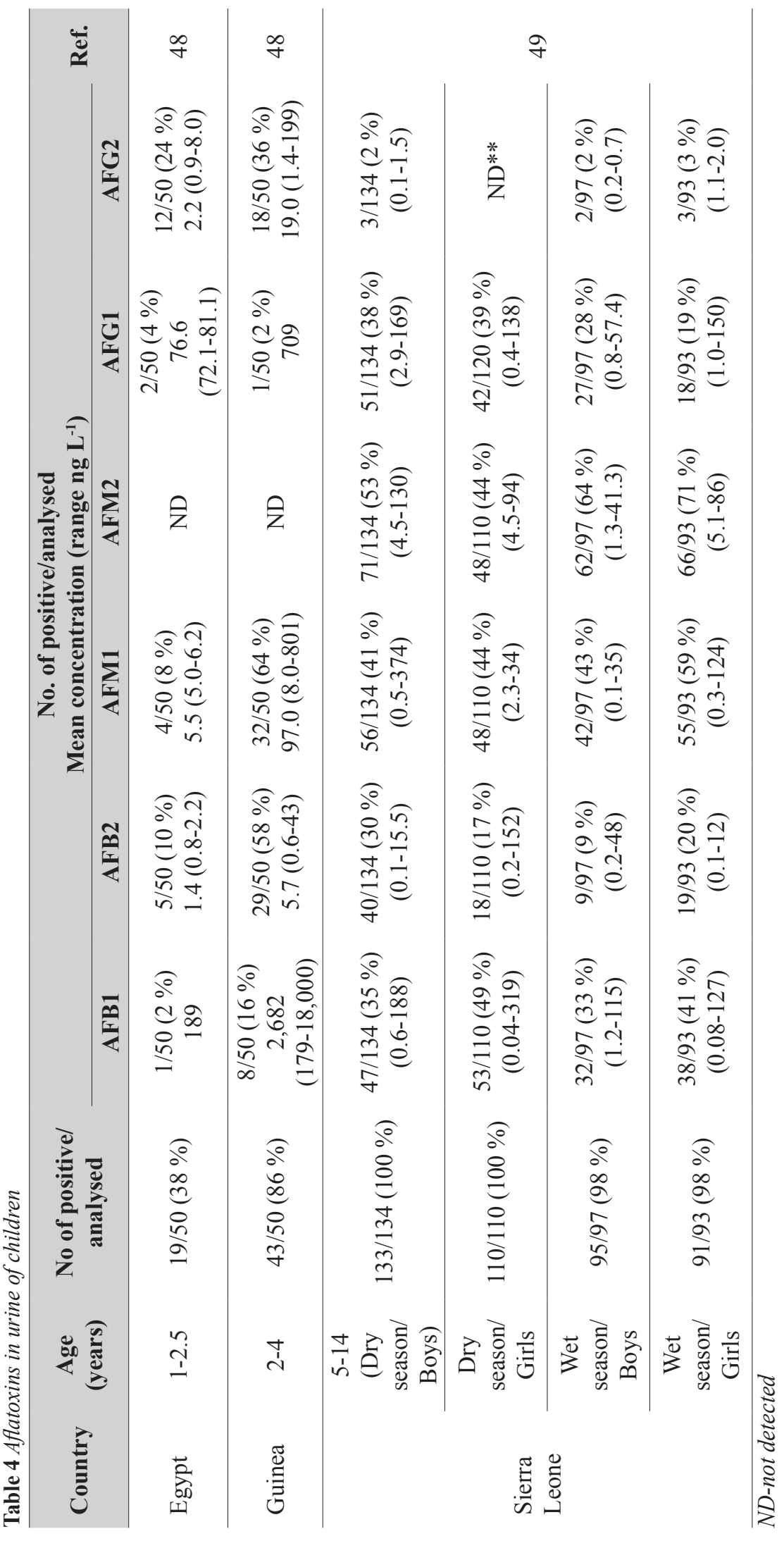


the children (96). Symptoms appeared 15 minutes to one hour after consuming contaminated bread; they were milder than in ATA and disappeared immediately after exposure ended. In the GI tract they included abdominal pain, diarrhoea, blood in the stool, and vomiting), but the most frequent were irritated throat and secondary infections of the upper respiratory tract.

Except for the study by Rubert et al. (97) there are no other reports of NIV and HT-2 toxin contamination of breast milk.

In animal studies trichothecenes turned out to be about 40 times more toxic when inhaled than when ingested (98). The outbreak of idiopathic pulmonary haemorrhage (IPH) in Cleveland (Ohio, US) between 1993 and 1998 involved 37 children, mostly African American, who lived in humid houses damaged by flooding or plumbing and roof leaks (99). IPH was associated with exposure to satratoxin $\mathrm{G}$ and $\mathrm{H}$ and roridin that are produced by Stachybotrys chartarum on water-soaked cellulose walls. In 12 children the outcome was fatal, and $60 \%$ of the children that returned home had recurrent pulmonary haemorrhage. It is not clear whether the toxins of $S$. chartarum caused IPH, as the Center of Disease Control declared that there was not enough evidence to confirm the suspicion (100).

\section{Zearalenone}

Zearalenone (ZEA) (previously also called F-2 toxin) is mainly produced by Fusarium moulds. ZEA is a field contaminant of wheat, maize, oats, and barley, particularly in warm and temperate climates (101). It can also be found in surface waters close to agricultural areas (102).

In humans, ZEA is rapidly absorbed by the GI tract and metabolised to $\alpha$-ZEA, $\beta$-ZEA, $\alpha$-zearalenol $(\alpha-Z A L)$, and $\beta$-zearalenol $(\beta-Z A L)$, which are then conjugated with glucuronic acid and rapidly excreted in bile and urine. Zearanol, a synthetic derivative of ZEA, is used as an anabolic agent for sheep and cattle in the USA, but in Europe it has been banned since 1989.

In experimental animals ZEA is hepatotoxic, haematotoxic, immunotoxic, and genotoxic (101). It has low acute toxicity, and there are no reports of acute human ZEA mycotoxicoses. At chronic levels, ZEA and its derivatives show oestrogenic effect by binding to oestrogenic receptors and by modulating the activity of aldo-keto-reductases involved in the steroid synthesis. In female experimental and domestic animals they cause infertility, reduce litter size, increase embryonic resorption, reduce milk production, hypertrophy mammal glands, change weight of the thyroid, pituitary, and adrenal glands, and increase oestrins. In male animals they reduce testis weight, testosterone production, spermatogenesis, and mating drive and lead to feminisation.

Studies on experimental animals showed that ZEA crosses the placental barrier and is also excreted in breast milk. In a recent Spanish study (97), ZEA was found in 13 out of 35 samples of human breast milk (37\%) and its metabolites $\alpha$-ZAL and $\beta$-ZAL in only one sample (2\%).

Historically, in Puerto Rico thousands of children experienced puberty, mainly due to environmental hormone contamination (103). Some of these children had ZEA in their blood, probably as the consequence of zearanol use as growth promoting agent in animal breeding. Since 1989, Hungary has seen an increase in the number of early telarche/mastopathy patients (104). Five out of them 36 had blood ZEA levels between 18.9 and $103.5 \mathrm{ng} \mathrm{mL}^{-1}$.

IARC has classified ZEA as a Group 3 carcinogen (66), but recent documents classify it and its metabolites as endocrine disruptors (105).

\section{Fumonisins}

Fumonisins are a group of 15 mycotoxins produced by Fusarium moulds (mostly $F$. verticilloides and $F$. moniliforme). In naturally contaminated grains the most frequent is fumonisin B1 (FB1), often accompanied by small amounts of fumonisin B2 (FB2) and fumonisin B3 (FB3).

Fumonisins contaminate various grains, but are most common in maize (106). They are poorly absorbed by the GI tract and quickly eliminated from plasma with low accumulation in the kidney and liver. They exert their toxic effects by inhibiting ceramide synthase, the key enzyme in the sphingolipid metabolism. This results in lower sphingolipid de novo synthesis and reuse of sphinganine. Significantly increased blood sphinganine affects the membrane transport of folic acid by binding to folate receptors, which eventually leads to lower folate uptake (107).

Fumonisins target different organs in domestic and experimental animals: in horses they cause leukoencephalomalacia, in pig pulmonary oedema, in rats they are predominantly nephrotoxic, and in mice they are hepatotoxic and teratogenic, causing neural tube defects (NTD) (2).

There is a only one report of acute fumonisincaused mycotoxicosis that occurred in India (108). 
Symptoms appeared after ingestion of contaminated sorghum or maize and included abdominal pain, borborygmi, and diarrhoea. The disease was selflimiting, and preschool children were less affected.

In some regions where maize is staple food (Transkei in Southern Africa, China, and Northern Italy) the high frequency of oesophageal cancers is believed to be related to exposure to fumonisins or their producers (F. moniliforme) $(109,110)$. In the early 1990s, a higher prevalence of NTD (anencephaly and spina bifida) was observed in children born along the Texan and Mexican border by Mexican-American women, and Hendricks et al. (111) suggested that this was caused by fumonisin exposure in the first trimester of pregnancy. High prevalence of NTD was also found in the Transkei region in Southern Africa (112), northern Iran (113), and several regions of China, where it was higher in rural than in urban population (114). In a large controlled study in China $(130,142$ women taking folic acid vs. 117,689 controls) the incidence of NTD was significantly decreased by folic acid supplementation (115). In Ireland, B12 and folic acid fortification of breakfast cereals decreased the rate of NTD from 47 to 13 per 10,000 births (116). In

Table 5 Ochratoxin A concentrations in breast milk

\begin{tabular}{|c|c|c|c|c|c|c|}
\hline Country & $\begin{array}{l}\text { No. of } \\
\text { positive/ } \\
\text { analysed }\end{array}$ & $\begin{array}{c}\text { Concentration } \\
\left(\text { ng L }{ }^{-1}\right) \\
\text { Mean } \pm \text { SD } \\
\text { (range) }\end{array}$ & Method & $\begin{array}{c}\text { LOD } \\
\left(n g L^{-1}\right)\end{array}$ & $\begin{array}{c}\text { LOQ } \\
\left(n g L^{-1}\right)\end{array}$ & Ref. \\
\hline \multicolumn{7}{|c|}{ Africa } \\
\hline \multirow[t]{2}{*}{ Egypt } & $43 / 120(36 \%)$ & $\begin{array}{c}21.06 \pm 13.7 \\
(5.07-45.01)\end{array}$ & HPLC-FD & NI & NI & 25. \\
\hline & $36 / 50(72 \%)$ & NI & HPLC/Mf & NI & NI & 78 \\
\hline Sierra Leone & $40 / 113(35 \%)$ & $\begin{array}{c}\text { NI } \\
200-337,000\end{array}$ & HPLC-FD & 200 & $\mathrm{NI}$ & 79 \\
\hline \multicolumn{7}{|c|}{ Americas } \\
\hline Brazil & $0 / 224$ & $\mathrm{NI}$ & HPLC-FD & $\mathrm{NI}$ & 0.0003 & 39 \\
\hline Sao Paolo & $2 / 50(4 \%)$ & 10,24 & HPLC-FD & NI & 10 & 38 \\
\hline $\begin{array}{l}\text { Ribeirão } \\
\text { Preto-SP }\end{array}$ & $66 / 100(66 \%)$ & $\begin{array}{c}4 \\
(0.3-21)\end{array}$ & HPLC-FD & 0.3 & 0.8 & 40 \\
\hline \multirow{2}{*}{ Chile } & 9/9 (100\%) & $\begin{array}{c}106 \pm 45 \\
(44-184)\end{array}$ & HPLC-FD & NI & NI & 77 \\
\hline & $40 / 50(80 \%)$ & $\begin{array}{c}52 \pm 56 \\
(10-186)\end{array}$ & HPLC-FD & 10 & 30 & 80 \\
\hline \multicolumn{7}{|c|}{ Asia } \\
\hline Iran, Sari & $2 / 136(1 \%)$ & 90,140 & $\begin{array}{c}\text { ELISA } \\
\text { HPLC-FD }\end{array}$ & NI & NI & 33 \\
\hline \multicolumn{7}{|c|}{ Australia } \\
\hline Victoria & $2 / 100(2 \%)$ & $3,3.6$ & HPLC-FD & 1.6 & NI & 81 \\
\hline \multicolumn{7}{|c|}{ Europe } \\
\hline \multirow{5}{*}{ Italy } & $9 / 50(18 \%)$ & $\begin{array}{c}4189 \\
(1700-6,600)\end{array}$ & HPLC-FD & 200 & NI & 82 \\
\hline & $22 / 111(20 \%)$ & $(100-12,000)$ & HPLC-FD & 100 & NI & 83 \\
\hline & $74 / 85(75 \%)$ & NI & NI & 20 & NI & 84 \\
\hline & $61 / 82(74 \%)$ & $\begin{array}{c}30.43 \pm 66.9 \\
(5-405)\end{array}$ & HPLC-FD & 2 & 5 & 36 \\
\hline & $198 / 231(86 \%)$ & $\begin{array}{c}6.01 \pm 8.31 \\
(1-57)\end{array}$ & HPLC-FD & 0.5 & NI & 35 \\
\hline \multirow[b]{2}{*}{ Norway } & $38 / 115(33 \%)$ & $(10-130)$ & HPLC-FD & $\mathrm{NI}$ & 10 & 85 \\
\hline & $17 / 80(21 \%)$ & $\begin{array}{c}30 \\
(10-182)\end{array}$ & HPLC-FD & NI & 10 & 86 \\
\hline Slovakia & $23 / 76(30 \%)$ & $(2.3-60.3)$ & HPLC-FD & 4.8 & 14.4 & 87 \\
\hline Sweden & $23 / 40(58 \%)$ & $(10-40)$ & HPLC-FD & 10 & 40 & 88 \\
\hline Switzerland & $4 / 40(10 \%)$ & $7.2(5-14)$ & HPLC-FD & NI & 5 & 76 \\
\hline Turkey & $75 / 75(100)$ & $(620-13,111)$ & HPLC-FD & 10 & NI & 37 \\
\hline
\end{tabular}


order to decrease the incidence of NTD, the US Food and Drug Administration (FDA) mandated fortification of grain products with folic acid (117). This resulted in lower NTD incidence in the general population, but not in several ethnic groups. There are reports of a $58 \%$ drop in NTD occurrence rate and of an even more significant (95\%) drop in NTD recurrence rate when folate supplementation was applied starting one month before conception (116). However, some studies reported that folate supplementation was not that effective or not effective at all, and the disturbance of folate metabolism by fumonisins has not been confirmed, although there is no doubt about their neurotoxicity in experimental animals (118-120).

IARC has classified fumonisins as carcinogenic in experimental animals with limited evidence of its carcinogenicity in humans (Group 2B carcinogen) (66).

\section{Ergot}

Ergot alkaloids are a group of about 40 toxins produced mostly by the fungal species of the genus Claviceps that contaminate rye, oats, and pearl millet. They are also produced by some strains of Penicillium, Aspergillus, and Rhizopus spp. (121). These toxins may be divided in three groups: lysergic acid derivatives (e.g. ergotamine and ergocristine), isolysergic acid drivatives (e.g. ergotaminine), and dimethylergoline derivatives (e.g. agroclavine) (122). Ergot is the name of sclerotia, a dark fungal mass that replaces the seed or kernel of the infected plant. Ergot poisoning is called ergotism and was common in European history (123).

The clinical presentation of acute ergotism depends on the type of toxins that are produced by particular strains of the genus Claviceps.

Ergot alkaloids are absorbed by the GI tract, distributed readily in plasma, and metabolised by CYP3A4. Some of them are conjugated with glucuronic acid and eliminated by biliary excretion (124).

Claviceps purpurea produces toxins from the group of lysergic acid derivatives (ergotamine and ergocristine), which cause severe vasoconstriction. Poisoning symptoms include severe pain in the legs, loss of pulse, and oedema. Paraesthesia is followed by gangrene around the tendons, with painless demarcation. In the ergotism outbreak in Wollo (Ethiopia) in 1977-78 four children lost one or both legs (125).
Clavine alkaloids produced by Claviceps fusiformis can cause the convulsive type of ergotism that occurs 1-48 hours after ingestion of contaminated food. It starts with gastrointestinal symptoms (nausea, vomiting, dizziness) and continues with the nervous system symptoms (crawling sensation in the skin, tingling in the fingers, vertigo, headache drowsiness, prolonged sleepiness, painful muscular contractions leading to convulsions, blindness, and paralysis). Mental disturbances may appear such as mania, psychosis, and delirium. One notable historical case presented by Caporeal (126) were the teenage girls accused of witchcraft in Salem in 1692.

\section{3-nitropropionic acid}

3-nitropropionic acid (3-NPA) is produced by Arthrinium moulds and causes the so called mouldy sugar cane disease (127). This disease appears in the late winter months (February and March) in 13 northern Chinese counties and affects children who consume sugar cane contaminated with Arthrinium moulds stored for at least two months. From 1978 to 1988, 884 persons were involved in a series of small epidemics (involving usually up to five children), and $88(10 \%)$ died (128). The first symptoms appeared two to three hours after the consumption of sugar cane and included vomiting, general fatigue, convulsions, carpopedal spasms, and coma. Dystonia appeared in $10-50 \%$ of the cases as the consequence of basal ganglia necrosis. These last symptoms can be predicted if the basal ganglia are scanned with computerised tomography (CT) (129). In adults, the symptoms of 3-NPA poisoning include mild disturbances of the GI tract and brain lesions, but these are very rare. Since 1995, there have been no further reports on mouldy sugar cane disease in the available scientific literature. However, Chinese health authorities keep issuing warnings in daily newspapers, which suggests that this disease is still a threat.

\section{Ustilago maydis toxins}

Historically, mycotoxicoses that appeared in Croatia between the two world wars were suspected to be caused by corn smut (Ustilago maydis). Children, infants, and toddlers, suspected of ustilaginism fell ill between March and May after a winter of almost exclusive consumption of corn flour from fields infested with corn smut. The clinical presentation was either acute - with acropathic symptoms including hand and sole pruritus, oedema and erythema - or 
chronic - with frequent relapses of acute symptoms and abundant skin desquamation $(130,131)$. At the time, it was believed that the cause were corn smut spores at a specific window of maturity. If the corn was consumed before or after that window, it was considered harmless. This corn smut hypothesis has never been confirmed, and the only argument in its favour is that the patient's condition would improve as soon (several days to a fortnight) as the corn flour was removed from the diet. No similar phenomena have been reported since 1945 .

\section{CONCLUSION}

Acute mycotoxicoses in children are serious diseases, mostly diagnosed only when an epidemics breaks out, affecting several children. They should be suspected when the disease cannot be explained by infection with a known microorganism. Acute mycotoxicoses are more frequent in tropical regions but are no stranger to temperate climates as well. Chronic mycotoxicoses may appear all over the world and paediatricians should keep in mind that their clinical manifestations vary a lot.

\section{REFERENCES}

1. Sherif SO, Salama EE, Abdel-Wahhab MA. Mycotoxins and child health: the need for risk assessment. Int J Hyg Environ Health 2009;212:347-68. doi: 10.1016/j.ijheh.2008.08.002

2. Domijan A-M, Peraica M. Carcinogenic mycotoxins. In: Comprehensive Toxicology, Vol.14, (Ed. McQueen A) Academic Press, Oxford 2010 pp. 125-137.

3. International Agency for Research on Cancer (IARC). IARC Monographs on the Evaluation of Carcinogenic Risks to Humans, Some traditional herbal medicines, some mycotoxins, naphthalene and styrene. Vol 82. Lyon: IARC; 2002.

4. Wojnowski L, Turner P C, Pedersen B, Hustert E, Brockmoller J, Maimuna M, Hilton C, Greg K, Wild CP. Increased levels of aflatoxin-albumin adducts are associated with CYP3A5 polymorphism in the Gambia, West Africa. Pharmacogenetics 2004;14:691-700. doi: 10.1097/00008571200410000-00007

5. Guengerich FP. Cytochrome P450 oxidations in the generation of reactive electrophiles: epoxidation and related reactions. Arch Biochem Biophys 2003;409:59-71. PMID: 12464245

6. Hengstler JG, van der Burg B, Steinberg P, Oesch F. Interspecies differences in cancer susceptibility and toxicity. Drug Metabol Rev 1999;31:917-70. PMID: 10575555

7. Klein PJ, Buckner R, Kelly J, Coulombe RA Jr. Biochemical basis for the extreme sensitivity of turkeys to aflatoxin $\mathrm{B}_{1}$.
Toxicol Appl Pharmacol 2000;165:45-52. doi: 10.1006/ taap. 2000.8926

8. Jackson PE, Groopman JD. Aflatoxin and liver cancer. Baillieres Best Pract Res Clin Gastroenterol 1999;13:545-55. PMID: 10654919

9. Turner PC, Sylla A, Kuang SY, Marchant CL, Diallo MS, Hall AJ, Groopman JD, Wild CP. Absence of TP53 codon 249 mutations in young Guinean children with high aflatoxin exposure. Cancer Epidemiol Biomarkers Prev 2005;14:205355. PMID: 16103461

10. Tsebe KV, Burnett RJ, Hlungwani NP, Sibara MM, Venter PA, Mphahlele MJ. The first five years of universal hepatitis $B$ vaccination in South Africa: evidence for elimination of HBsAg carriage in under 5-years-old. Vaccine 2001;19:391926. PMID: 11427266

11. Ediage EN, Di Mavungu JD, Song S, Sioen I, De Saeger S. Multimycotoxin analysis in urines to assess infant exposure: A case study in Cameroon. Envirn Int 2013;57-58; 50-9. doi: 10.1016/j.envint.2013.04.002

12. Amla I, Kamala CS, Gopalakrishna GS, Jayaraj AP, Sreenivasamurthy V, Parpia HAB. Cirrhosis in children from peanut meal contaminated by aflatoxin. Am J Clin Nutr 1971;24:609-14. PMID: 5581000

13. Krisnamashari KAVR, Bhat RV, Nagarajan V, Tilak TBG. Hepatitis due to aflatoxicosis. Lancet 1975;1:1061-3. doi: 10.1016/S0140-6736(75)91829-2

14. Tandon BN, Krishnamurthy L, Koshy A, Tandon HD, Ramalingaswami V, Bhandari JR, Mathur MM, Mathur PD. Study of an epidemic of jaundice, presumably due to toxic hepatitis, in Northwest India. Gastroenterology 1977;72:48894. PMID: 832797

15. Ngindu A, Johnson BK, Kenya PR, Ngira JA, Ocheng DM, Nandwa H, Omondi TN, Jansen AJ, Ngare W, Kaviti JN, Gatei D, Siongok TA. Outbreak of acute hepatitis caused by aflatoxin poisoning in Kenya. Lancet 1982;319:1346-8. doi: 10.1016/S0140-6736(82)92411-4

16. Obura A. Aflatoxicosis: evidence from Kenya [displayed 22 July 2014]. Available at http://www.ifpri.org/sites/default/ files/publications/focus20 02.pdf

17. Lamplugh SM, Hendrickse RG, Apeagyei F, Mwanmut DD. Aflatoxins in breast milk, neontal cord blood, and serum of pregnant women. Br Med J 1988;296:968. doi: 10.1136/ bmj.296.6627.968

18. Abdulrazzaq YM, Osman N, Ibrahim A. Fetal exposure to aflatoxins in United Arab Emirates. Ann Trop Paediatr 2003;22:3-9. doi: 10.1179/027249302125000094

19. Turner PC, Collinson AC, Cheung YB, Gong YY, Hall AJ, Prentice AM, Wild CP. Aflatoxin exposure in utero causes growth flatering in Gambian infants. Int J Epidemiol 2007;36:1119-25. doi: 10.1093/ije/dym122

20. Mahdavi R, Nikniaz L, Arefhosseini SR, Vahed Jabbari M. Determination of aflatoxin M1 in breast milk samples in Tabriz-Iran. Matern Child Health J 2010;14;141-5. doi: 10.1007/s10995-008-0439-9

21. Zarba A, Wild CP, Hall AJ, Montesano R, Hudson GJ, Groopman JD. Aflatoxin M1 in human breast milk from Gambia, West Africa, quantified by combined monoclonal antibody immunoaffinity chromatography and HPLC. Caracinogenesis 1992;13:891-4. PMID: 1587004

22. Adejumo O, Atanda O, Raiola A, Somorin Y, Bandyopadhyay $\mathrm{R}$, Ritieni A. Correlation between aflatoxin M1 content of breast milk, dietary exposure to aflatoxin $\mathrm{B} 1$ and socieconomic 
status of lactating mothers in Ogun State, Nigeria. Food Chem Toxicol 2013;56:171-7. doi: 10.1016/j.fct.2013.02.027

23. Gong YY, Hounsa A, Egal S, Turner PC, Sutcliffe AE, Hall AJ, Cardwell K, Wild CP. Postweaning exposure to aflatoxin results in impaired child growth: a longitudinal study in Benin, West Africa. Environ Health Perspect 2004;112:13348. PMID: 15345349

24. Tchana AN, Moundipa PF, Tchouanguep FM. Aflatoxin contamination in food and body fluids in relation to malnutrition and cancer status in Cameroon. Int J Environ Res Public Health 2010;7:178-88. doi: 10.3390/ ijerph7010178

25. El-Sayed AA, Soher ES, Neamat-Allah AA. Human exposure to mycotoxins in Egypt. Mycotox Res 2002;18:23-30. doi: 10.1007/BF02946136

26. Polychronaki N, West RM, Turner PC, Amra H, AbdelWahhab M, Mykkänen H, El-Nezami H. A logitudinal assessment of aflatoxin M1 excretion in breast milk of selected Egyptian mothers. Food Chem Toxicol 2007;45:1210-5. doi: 10.1016/j.fct.2007.01.001

27. El-Tras WF, El-Kady NN, Tayel AA. Infants exposure to aflatoxin M1 as a novel foodborne zoonosis. Food Chem Toxicol 2011;49:2816-9. doi: 10.1016/j.fct.2011.08.008

28. Coulter JB, Lamplugh SM, Suliman GL, Omer MI, Hendrickse RG. Aflatoxins in human breast milk. Ann Trop Pediatr 1984;4:61-6. PMID: 6083747

29. Elzupir AO, Abas AR, Fadul MH, Modwi Ak, Ali NM, Jadian AF, Ahmed NA, Adam SY, Ahmed NA, Kahiry AA, Khalil EA. Aflatoxin M1 in breast milk of nursing Sudanese mothers. Mycotoxin Res 2012;28:131-4. doi: 10.1007/ s12550-012-0127-x

30. Wild CP, Pionneau FA, Montesanto R, Mutiro CF, Chetsanga CJ. Aflatoxin detected in human breast milk by immunoassay. Int J Cancer 1987;40:328-33. doi: 10.1002/ijc.2910400308

31. Sharaf OS. Incidence of aflatoxin M1 in human milk and animal milk from Jordan. J Toxicol Environ Health 2012;75:1404-9. doi: 10.1080/15287394.2012.721174

32. Ghiasain SA, Maghsood AH. Infants's exposure to aflatoxin M1 from mother's breast milk in Iran. Iran J Publ Health 2012;41:119-26. PMCID: PMC3481700

33. Afsahar P, Shokrzadeh M, Kalhori S, Babaee Z, Saeedi Saravi SS. Occurrence of ochratoxin A and aflatoxin M1 in human breast milk in Sari, Iran. Food Control 2013;31:525-9. doi: 10.1016/j.foodcont.2012.12.009

34. Sadeghi N, Oveisi MR, Jannat B, Hajimahmoodi M, Boyani $\mathrm{H}$, Jannat $\mathrm{F}$. Incidence of aflatoxin $\mathrm{M} 1$ in human breast milk in Tehran, Iran. Food Control 2009;20:75-8. doi: 10.1016/j. foodcont.2008.02.005

35. Turconi G, Guarcello M, Livieri C, Comizzoli S, Maccaraini L, Castellazzi AM, Pietri A, Piva G. Evaluation of xenobiotics in human milik and ingestion by newborn - an epidemiological survey in Lombardi (Northern Italy). Eur J Nutr 2004;43:1917. PMID: 15309437

36. Galvano F, Pietri A, Bertuzzi T, Gagliardi L, Ciotti S, Luisi S, Bognano M, La Fauci L, Iacopino AM, Nigro F, Li Volti G, Vanella L, Giammanco G, Tina GL, Gazzolo D. Maternal dietary habits and mycotoxin occurrence in human mature milk. Mol Nutr Food Res 2008;52:496-501. doi: 10.1002/ mnfr.200700266

37. Gürbay A, Sabuncuoglu SA, Girgin G, Sahin G, Yigit S, Yurdakok M, Tekinalp G. Exposure of newborns to aflatoxin M1 and B1 from mothers' breast milk in Ankara, Turkey.
Food Chem Toxicol 2010;48:314-9. doi: 10.1016/j. fct.2009.10.016

38. Navas SA, Sabino M, Rodriguez-Amaya DB. Aflatoxin M1 and ochratoxin A in a human milk bank in the city of São Paolo, Brazil. Food Addit Contam 2005;22:457-62. PMID: 16019818

39. Andrade PD, Gomes da Silva JL, Dutra Caldas ED. Simultaneous analysis of aflatoxins B1, B2, G1, G2, M1 and ochratoxin $\mathrm{A}$ in breast milk by high-performance liquid chromatography/fluorescence after liquid-liquid extraction with low temperature purification (LLE-LTP). J Chromatography A 2013;1304:61-8. doi: 10.1016/j. chroma.2013.06.049

40. Iha MH, Barbosa CB, Heck AR, Trucksess MW. Aflatoxin M1 and ochratoxin A in human milk in Ribeirão Preto-SP, Brazil. Food Control 2014;40:310-3. doi: 10.1016/j. foodcont.2013.12.014

41. Turner PC, Mendy M, Whittle H, Fortuin M, Hall AJ, Wild CP. Hepatitis B infection and aflatoxin biomarker levels in Gambian children. Trop Med Int Health 2000;5:837-41. PMID: 11169271

42. Gong YY, Egal S, Hounsa A, Turner PC, Hall AJ, Cardwell $\mathrm{KF}$, Wild CP. Determinants of aflatoxin exposure in young children from Benin and Togo, West Africa: the critical role of weaning. Int J Epidemiol 2003;32:556-62. PMID: 12913029

43. El-Morsi DA, Shabaan S, Abdelhamid AM, Mehrim AI, Shoulman BO. Aflatoxin B1 level in relation to child's feeding and growth. Mansoura J Forensic Med Clin Toxicol 2010;28:1-13

44. Tonon KM, Reiter MGR, Scussel VM. Mycotoxins levels in human milk: a menace to infants and children health. Curr Nutr Food Sci 2013;9:33-42. doi : 10.2174/1573401311309010007

45. Marin S, Ramos AJ, Cano-Sancho G, Sanchis V. Mycotoxins: Occurence, toxicology and exposure assessment. Food Chem Toxicol 2013;60:218-37. doi: 10.1016/j.fct.2013.07.047

46. Gong YY, Cardwell K, Hounsa A, Egal S, Turner PC, Hall AJ, Wild CP. Dietary aflatoxin exposure and impaired growth in young children from Benin and Togo: cross sectional study. Br Med J 2002;325:20-1. doi: 10.1136/bmj.325.7354.20

47. Chen SY, Chen CJ, Chou SR, Hsieh LL, Wang LY, Tsai WY, Ahsan H, Santella RM. Association if aflatoxin B1-albumin adduct levels with hepatitis B surface antigen status among adolescents in Taiwan. Cancer Epidemiol Biomarkers Prev 2001;10:1223-6. PMID: 11700273

48. Polychronaki N, Wild CP, Mykkänen H, Amra H, AbdelWahhab M, Sylla A, Diallo M, El-Nezami H, Turner PC. Urinary biomarkers of aflatoxin exposure in young children from Egypt and Guinea. Food Chem Toxicol 2008;46:51926. doi: 10.1016/j.fct.2007.08.034

49. Jonsyn-Ellis FE. Seasonal variation in exposure frequency and concentration levels of aflatoxins and ochratoxins in urine samples of boys and girls. Mycopatologia 2000;152:3540. doi: 10.1023/A:1011950512675

50. Jiang Y, Jolly PE, Ellis WO, Wang J-S, Phillips TD, Williams $\mathrm{JH}$. Aflatoxin B1 albumin adduct levels and cellular immune status in Ghanaians. Int Immunol 2005;17:807-14. doi: 10.1093/intimm/dxh262

51. Denning DW, Quiepo SC, Altman DG, Makarananda K, Neal GE, Camallere EL, Morgan MR, Tupasi TE. Aflatoxin and outcome from acute lower respiratory infection in children 
in The Philippines. Ann Trop Pediatr 1995; 15:209-16. PMID 8534039

52. Oyelami OA, Maxwell SM, Adelusola KA, Aladekoma TA, Olyelese AO. Aflatoxins in the lungs of children with kwashiorkor and children with miscellaneous diseases in Nigeria. J Toxicol Environ Health 1997;51:623-8. PMID: 9242232

53. Jonsyn-Ellis FE. Ignored aetiologic factors of growth faltering/stunting in Sierra Leonean Children: aflatoxin and ochratoxin A. Sierra Leone J Biomed Res 2012;4:14-21.

54. Sodeinde O, Chan MCK, Maxwell SM, Familusi JB, Hendrickse RG. Neonatal jaundice, aflatoxins and naphtols: report of a study in Ibadan, Nigeria. Ann Trop Pediatr 1995;15:107-13. PMID: 7677410

55. Gong YY, Wilson S, Mwatha JK, Routledge MN, Castelino JM, Zhao B, Kimani G, Kuruki HC, Vannervald BJ, Dunne DW, Wild CP. Aflatoxin exposure may contribute to chronic hepatomegaly in Kenyan school children. Environ Health Perspect 2012;120:893-6. doi: 10.1289/ehp.1104357

56. McGovern MC, Glasgow JFT, Stewart MC, Reye's syndrome and aspirin: lest we forget. Brit Med J 2001:322:1591-2.

57. Schror K. Aspirin and Reye syndrome: a review of the evidence. Paediatr Drugs 2007; 9:195-204.

58. International Programme on Chemical Safety (IPCS). Safety evaluation of certain mycotoxins in food. WHO Food Additives Series. Vol 47. Geneva: WHO; 2001.

59. Zepnik H, Völkel W, Dekant W. Toxicokinetics of the mycotoxin ochratoxin A in F 344 rats after oral administration. Toxicol Appl Pharmacol 2003;192:36-44. PMID: 14554101

60. Studer-Rohr I, Schlatter J, Dietrich DR. Kinetic parameters and intraindividual fluctuations of ochratoxin A plasma levels in humans. Arch Toxicol 2000;74:499-510. PMID: 11131029

61. Ringot D, Chango A, Schneider Y-J, Larondelle Y. Toxicokinetics and toxicodynamics of ochratoxin $\mathrm{A}$, an update. Chem Biol Interact 2006;159:18-46. PMID: 16293235

62. Želježić D, Domijan A-M, Peraica M. DNA damage by ochratoxin A in rat kidney assessed by alkaline comet assay. Braz J Med Biol Res 2006;39:1563-8. PMID: 17160264

63. Domijan A-M, Želježić D, Kopjar N, Peraica M. Standard and Fpg-modified comet assay in kidney cells of ochratoxin A- and fumonisin B1-treated rats. Toxicology 2006;222:539. doi: 10.1016/j.tox.2006.01.024

64. Šegvić Klarić M, Želježić D, Rumora L, Peraica M, Pepeljnjak S, Domijan A-M. A potential role of carlcium in apoptosis and aberrant chromatin forms in porcine kidney PK15 cells induced by individual and combined ochratoxin a and citrinin. Arch Toxicol 2012;86:97-107.

65. Limonciel A, Jennings P. A review of evidence that ochratoxin A is a NrF2 inhibitor:Implications for nephrotoxicity and renal carcinogenicity. Toxins 2014;6:371-379. doi: 10.3390/ toxins 6010371

66. International Agency for Research on Cancer (IARC). IARC Monographs on the Evaluation of Carcinogenic Risks to Humans, Some naturally occurring substances: food items and constituents, heterocyclic aromatic amines and mycotoxins. Vol 56. Lyon: IARC; 1993.

67. Di Paolo N, Guarnieri A, Garossi G, Sacchi G, Mangiarotti AM, Di Paolo M. Inhaled mycotoxins lead to acute renal failure. Nephrol Dial Transplant 1994;9(Suppl 4):116-20. PMID: 7800243
68. Miletić-Medved M, Domijan A-M, Peraica M. Recent data on endemic nephropathy and related urothelial tumors in Croatia. Wien Klin Wochenschr 2005;117:604-9. PMID: 16395990

69. Pfohl-Leszkowicz A. Ochratoxin A and aristolochic acid involvement in nephropathies and associated urothelial tract tumours. Arh Hig Rada Toksikol 2009;60:465-83. doi: 10.2478/10004-1254-60-2009-2000

70. Pfohl-Leszkowicz A, Manderville RA. Ochratoxin A: and overview on toxicity and carcinogenicity in animals and humans. Mol Nutr Food Res 2007;51:61-99. PMID: 17195275

71. Peraica M, Domijan A-M, Fuchs R. Lucić A, Radić B. The occurrence of ochratoxin A in blood in general population of Croatia. Toxicol Lett 1999:110:105-12. PMID: 10593601

72. Peraica M, Domijan A-M, Matašin M, Lucić A, Radić B, Delaš F, Horvat I, Bosanac I, Balija M, Grgičević D. Variations of ochratoxin A concentration in the blood of healthy populations in some Croatian cities. Arch Toxicol 2001;75:410-4. PMID: 11693182

73. Fuchs R, Peraica M. Ochratoxin A in human kidney diseases. Food Addit Contam 2005; 22 (Suppl 1).53-57. doi:10.1080 102652030500030936895.

74. Verger Ph, Counil E, Tressou J, Leblanc JC. Some recent advances in modelling dietary exposure to ochratoxin A. Food Add Contam 2005; 22(supl 1): 94-98. doi: 10.1080/02652030500410281

75. EFSA. Opinion of the Scientific Panel on contaminants in the food chain on a request from the Commission related to ochratoxin A in food. EFSA J 2006; 365: 1-56.

76. Zimmerli B, Dick R. Determination of ochratoxin A at the ppt level in human blood, serum, milk and some foodstuffs by high-performance liquid chromatography with enhanced fluorescence detection and immunoaffinity column cleanup: methodology and Swiss data. J Chromatogr B Biomed Appl 1995;666:85-99. PMID: 7655625

77. Muñoz K, Campos V, Blaszkewicz M, Vega M, Alvarez A, Neira J, Degen GH. Exposure of neonates to ochratoxin A: first biomonitoring results in human milk (colostrum) from Chile. Mycotoxin Res 2010;26:59-67. doi: 10.1007/s12550009-0040-0

78. Hassan AH, Sheashaa HA, Fattah MFA, Ibrahim AZ, Gaber OA, Sobh MA. Study of ochratoxin A as an environmental risk that causes renal injury in breast-fed Egyptian infants. Pediatr Nephrol 2006;21:102-5. doi: 10.1007/s00467-0052033-3

79. Jonsyn FE, Maxwell SM, Hendrickse RG. Ochratoxin A and aflatoxins in breast milk samples from Sierra Leone. Mycopathologia 1995;131:121-6. doi: 10.1007/BF01102890

80. Muñoz K, Blaszkewicz M, Campos V, Vega M, Degen GH. Exposure of infants to ochratoxin with breast milk. Arch Toxicol 2014;88:837-846. doi: 10.1007/s00204-013-1168-4

81. Apostolou E, E-Nezami HS, Ahokas JT, Donohue DC. The evaluation of ochratoxin A in breast milk in Victoria (Australia). Revue Méd Vét 1998;149:709.

82. Micco C, Ambruzzi MA, Miraglia M, Brera C, Onori R, Benelli L. Contamination of human milk with ochratoxin A. In: Castegnaro M, Pleština R, Dirheimer G, Chernozemsky IN, Bartsch H, editors. Mycotoxins, endemic nephropathy and urinary tract tumours. IARC Scientific Publications No. 115. Lyon: IARC; 1991. p. 105-11. 
83. Micco C, Miraglia M, Brera C, Corneli S, Ambruzzi A. Evaluation of ochratoxin A level in human milk in Italy. Food Addit Contam 1995;12:351-4. PMID: 7664927

84. Miraglia M, Brera C, Cava E, Calfapietra FR. The evaluation of major sources of ochratoxin $\mathrm{A}(\mathrm{OA})$ intake through the analysis of OA in biological fluids in Italy. Revue Méd Vét 1998;149:711.

85. Skaug MA, Størmer FC, Saugstad OD. Ochratoxin A: a naturally occurring mycotoxin found in human milk samples from Norway. Acta Paediatr 1998;87:1275-8. doi: 10.1111/ j.1651-2227.1998.tb00951.x

86. Skaug MA, Helland I, Solvoll K, Saugstad OD. Presence of ochratoxin A in human milk in relation to dietary intake. Food Addit Contam 2001;18:321-7. PMID: 11339267

87. Dostal A, Jakusova L, Cajdova J, Hudeckova H. Results of the first studies of occurrence of ochratoxin A in human milk in Slovakia. Bratisl Lek Listy 2008;109:276-8. PMID: 18700441

88. Breitholtz-Emanuelsson A, Olsen M, Oskarsson A, Palminger I, Hult K. Ochratoxin A in cow's milk and in human milk with corresponding human blood samples. J AOAC Int 1993;76:842-6. PMID: 8374329

89. Schwartz GG. Hypothesis: does ochratoxin A cause testicular cancer? Cancer Causes Contr 2002;13:91-100. PMID: 11899122

90. Pestka JJ, Zhou HR, Moon Y, Chung YJ. Cellular and molecular mechanisms for immune modulation by deoxynivalenol and other trichothecenes: unraveling a paradox. Toxicol Lett 2004;153:61-73. PMID: 15342082

91. Antonissen G, Martel A, Pasmans F, Ducatelle R, Verbrugghe E, Vandenbroucke V, Li S, Haesebrouck F, Van Immerseel $\mathrm{F}$, Croubels S. The impact of fusarium mycotoxins on human and animal host susceptibility to infectious diseases. Toxins 2014; 6:430-52. doi: 10.3390/toxins6020430

92. EFSA. Scientific opinion on risk for animal and public health related to the presence of nivalenol in food and feed. EFSA J 2013;11:1-119. doi: 10.2903/j.efsa.2013.3262

93. EFSA. Deoxynivalenol in food and feed: occurrence and exposure. EFSA J 2013:11:1-56. doi: 10.2903/j. efsa.2013.3379

94. EFSA. Scientific opinion on the risks for animal and public health related to the presence of T-2 and HT-2 toxin in food and feed. EFSAJ 2011;9:1-187. doi: 10.2903/j.efsa.2011.2481

95. Gajdušek DC. Acute Infectious Hemorrhagic Fevers Mycotoxicoses in the Union of Soviet Socialist Republics. Medical Science Publications No 2. Washington: Walter Reed Army Medical Center; 1953.

96. Bhat RV, Beedu SR, Ramakrishna Y, Munsh KL. Outbreak of trichothecene mycotoxicosis associated with consumption of mould-damaged wheat products in Kashmir Valley, India. Lancet 1989;333:35-7. doi: 10.1016/S0140-6736(89)91684-X

97. Rubert J, Leon N, Saez C, Martins CPB, Godula M, Yusa V, Manes J, Sorina JM, Soler C. Evaluation of mycotoxins and their metabolites in human breast milk using liquid chromatography coupled to high resolution mass spectrometry. Analyt Chim Acta 2014;820:39-46. doi: 10.1016/j.aca.2014.02.009

98. Smoragiewicz W, Cossette B, Boutard A, Krzystyniak K. Trichothecene mycotoxins in the dust of ventilation systems in office buildings. Int Arch Occup Environ Health 1993;65:113-7. doi: 10.1007/BF00405729
99. Dearborn DG, Yike I, Sorenson WG, Miller MJ, Etzel RA. Overview of investigations into pulmonary hemorrhage amogn infants in Cleveleand, Ohio. Environ Health Perspect 1999;107(Suppl 3):495-9. PMID: 10346998

100. Center for Disease Control. Update: Pulmonary hemorrhage/ hemosiderosis among infants - Cleveland, Ohio, 1993-1996. CDC MMWR 2000;49:180-4.

101. Zinedine A, Soriano JM, Moltó JC, Mañes J. Review on the toxicity, occurrence, metabolism, detoxification, regulations and intake of zearalenone: an oestrogenic mycotoxin. Food Chem Toxicol 2007;45:1-18. PMID: 17045381

102. Waskiewicz A, Gromadzka K, Bocianowski J, Pluta P, Golinski P. Zearalenone contamination of the aquatic environment as a result of its presence in crops. Arh Hig Rada Toksikol 2012;63:429-35. doi: 10.2478/10004-125463-2012-2229

103. Saenz de Rodriguez CA. Envirnomental hormone contamination in Puerto Rico. New Engl J Med 1984;310:1741-42. PMID: 6233490

104. Szuets P, Meserhazy A, Falklay GY, Bartok T. Early thelarche symptoms in children and their relations to zearalenon contamination in foodstuffs. Cereal Res Commun 1997;25:429-36.

105. EFSA. Scientific opinion on the risk for public health related to the presence of zearalenone in food. EFSA J 2011:9:1-91. doi: 102903/j.efsa.2011.2197

106. Sorriano JM, Dragacci S. Occurrence of fumonisins in foods. Food Res Int 2004;37:985-1000. doi: 10.1016/j. foodres.2004.06.009

107. Stevens VL, Tang J. Fumonisin B1-induced sphingolipid depletion inhibits vitamin uptake via the glycosylphosphatidylinositol-anchored folate receptor. J Biol Chem 1997;272:18020-5. doi: 10.1074/jbc.272.29.18020

108. Bhat RV, Shetty PH, Amruth RP, Sudershan RV. A foodborne disease outbreak due to the consumption of moldy sorghum and maize containing fumonisin mycotoxins. J Toxicol Clin Toxicol 1997;35:249-55. PMID: 9140318

109. Marasas WFO, Jaskiewicz K, Venter FS, Van Schalkwyk DJ. Fusarium moniliforme contamination of maize in esophageal cancer aereas in Transkei. S Afr Med J 1988;74:110-4. PMID: 3399988

110. International Programme on Chemical Safety (IPCS). Fumonisin B1. Environmental Health Criteria. Vol 219. Geneva: WHO; 2000.

111. Hendricks KA, Simpson JS, Larsen RD. Neural tube defect along the Texas-Mexico border, 1993-1995. Am J Epidemiol 1999;149:119-27. PMID: 10369506

112. Ncayiyana DJ. Neural tube defects among rural blacks in a Transkei district. A preliminary report and analysis. S Afr Med J 1986;69:618-20. PMID: 3704839

113. Golalipour MJ, Mobasheri E, Vakili MA, Keshtkar AA. Epidemiology of neural tube defects in northern Iran, 19982003. East Mediterr Health J 2007;13:560-6. PMID: 17687828

114. Lian ZH, Yang HY, Li Z. Neural tube defects in BeijingTianjin area of China. Urban-rural distribution and some other epidemiological characteristics. J Epidemiol Commun Health 1987;41:259-62. PMID: 3443820

115. Berry RJ, Li Z, Erickson D, Li S, Moore CA, Wang H, Mulinare J, Zhao P, Wong L-YC, Gindler J, Hong S-X. Prevention of neural-tube defects with folic acid in China. 
N Engl J Med 1999;341:1485-90. doi: 10.1056/ NEJM199911113412001

116. Digra NC. Primary prevention of neural tube defects. JK Science 2004;6:1-3.

117. Williams LJ, Rasmussen SA, Flores A, Kirby RS, Edmonds LD. Decline in prevalence of spina bifida and anencephaly by race/ethnicity: 1995-2002. Pediatrics 2005;116:580-6. doi: 10.1542/peds.2005-0592

118. Hendricks K, Larsen R, Suarez L. Neural tube defect surveillance and folic acid intervention - Texas Mexico Border, 1993-1998. CDC MMWR 2000;49:1-4.

119. Suarez L, Hendircks KA, Cooper SP, Sweeney AM, Hardy RJ, Larsen RD. Neural tube defects among Mexican Americans livnig on US-Mexico border: effects of folic acid and dietary folate. Am J Epidemiol 2000;152:1017-23. doi: 10.1093/aje/152.11.1017

120. Domijan A-M. Fumonisin B1: a neurotoxic mycotoxin. Arh Hig Rada Toksikol 2012;63:531-44. doi: 10.2478/100041254-63-2012-2239

121. Flieger M, Wurst M, Shelby R. Ergot alkaloids - sources, structures and analytical methods. Folia Microbiol (Praha) 1997; 42:3-30. PMID:9160999

122. World Health Organization (WHO). Selected mycotoxins: ochratoxins, trichothecens, ergot. Report of an Expert Committee. Environmental Health Criteria No. 105. Geneva: WHO; 1990.
123. Peraica M, Rašić D. The impact of mycotoxicoses on human history. Arh Hig Rada Toksikol 2012;63:511-6. doi: 10.2478/10004-1254-63-2012-2259

124. EFSA. Scientific opinion on ergot alkaloids in food and feed. EFSA J 2012;10:1-158. doi: 10.2903/j.efsa.2012.2798

125. King B. Outbreak of ergotism in Wollo, Ethiopia. Lancet 1979;1(8131):1411. PMID: 87875

126. Caporeal LR. Ergotism: The satan losed in Salem? Science 1976;192:21-6. doi: 10.1126/science.769159

127. Liu X, Luo X, Hu W. Arthrinium sp. and the deteriorated sugarcane poisoning. In: Aibara K, Kumagai S, Ohtsubo K, Yoshizawa T, editors. Mycotoxins and phycotoxins, Abstracts of the Seventh International IUPAC Symposium, Tokyo 1988. Tokyo: Japanese Association of Mycotoxicology; 1988. p. 26

128. Liu X, Luo X, Hu W. Studies on epidemiology and etiology of moldy sugarcane poisoning in China. Biomed Environ Sci 1992;5:161-77. PMID: 1642790

129. Ming L. Moldy sugarcane poisoning - a case report with a brief review. J Toxicol Clin Toxicol 1995;33:363-7. PMID: 7629905

130. Urbany M. Dva daljnja slučaja ustilaginizma [Two new cases of ustilagnism, in Croatian]. Liječ Vjesn 1942;64:165-9.

131. Urbany M. Slučaj infantilne akrodinije s recidivom [Case of acrodinia with recidivism, in Croatian]. Liječ Vjesn 1943;65:159-62. 


\section{Sažetak}

\section{Mikotoksikoze u djece}

Mikotoksikoze su akutna i kronična trovanja toksinima plijesni koji se nazivaju mikotoksini. Odrasle osobe i djeca stalno su izloženi niskim koncentracijama mješavine mikotoksina, većinom putem kontaminirane hrane. Akutne toksikoze koje uzrokuje izloženost velikim količinama mikotoksina danas su rijetke te su opisane kako bi se liječnici i drugo zdravstveno osoblje informirali o njihovim simptomima koji mogu oponašati druge bolesti. Djeca su osjetljivija na toksični učinak mikotoksina zbog toga što je njihova tjelesna masa manja, a neki sustavi za detoksikaciju nisu u potpunosti razvijeni. Neke se mikotoksikoze javljaju samo u djece ili su u djece simptomi jače izraženi. Podrobnih podataka o epidemiologiji mikotoksikoza u dječjoj dobi nema jer one pogađaju prvenstveno najsiromašnije, uglavnom u zemljama tropskoga pojasa gdje je zdravstvena služba nedostatna, a potrebe stanovništva za liječenjem velike. U tim se zemljama češće javljaju i kronične mikotoksikoze, no ima ih i u zemljama s umjerenom klimom. U razvijenim su zemljama zdravstvene vlasti više zabrinute zbog izloženosti djece niskim koncentracijama mikotoksina koji imaju imunotoksična, genotoksična i kancerogena svojstva.

KLJUČNE RIJEČI: 3-NPA; aflatoksini; ergot; fumonizini; okratoksini; trihoteceni; toksini Ustilago maydis; zearalenon

\section{CORRESPONDING AUTHOR:}

Maja Peraica, MD, PhD

Institute for Medical Research and Occupational Health

Ksaverska cesta 2, 10001 Zagreb, Croatia

E-mail: mperaica@imi.hr 